\title{
PENGEMBANGAN MEDIA INTERAKTIF PROGRAM LECTORA INSPIRE BERBASIS ANDROID PADA MATERI JURNAL PENYESUAIAN PERUSAHAAN JASA KELAS XI AKUNTANSI DAN KEUANGAN LEMBAGA SMK NEGERI 10 SURABAYA
}

\author{
Mely Tri Octavina1), Susanti ${ }^{2}$ \\ 1,2Fakultas Ekonomika dan Bisnis, Universitas Negeri Surabaya \\ Email: melytri3octavina@gmail.com, susanti@unesa.ac.id
}

\begin{abstract}
ABSTRAK
Perkembangan IPTEKS pada era revolusi industri 4.0 serta berlakunya sistem kurikulum 2013 dalam pembelajaran, guru diharapkan dapat menyesuaikan perkembangan zaman yang ada. Salah satu cara untuk memanfaatkan teknologi yang ada adalah dengan mengembangkan media interaktif dengan memanfaatkan smartphone android. Dengan memanfaatkan smartphone android berbantu aplikasi yang menarik peserta didik dapat belajar kapanpun dan dimanapun sehingga pembelajaran berlangsung dengan baik.Terdapat beberapa aplikasi yang beragam untuk mendukung media interaktif salah satunya yakni Lectora Inspire. Tujuan dari penelitian ini ialah untuk mengembangkan media interaktif program Lectora Inspire berbasis android pada materi jurnal penyesuaian perusahaan jasa. Penelitian ini merupakan jenis penelitian pengembangan yang mengadaptasi model pengembangan 4D dari Thiagarajan meliputi tahap pendefinisian, perancangan, pengembangan dan penyebarluasan. Namun dengan keterbatasan kemampuan dan keterjangkauan penelitian ini hanya melalui tiga tahap. Subjek uji coba penelitian adalah ahli materi, ahli media dan 20 peserta didik kelas XI Akuntansi dan Keuangan Lembaga 4 SMK Negeri 10 Surabaya. Menggunakan angket sebagai instrumen penelitian, serta analisis deskriptif kuantitatif sebagai teknik analisis data. Untuk mengetahui tingkat kelayakan media interaktif dilakukan beberapa langkah yakni telaah media, revisi, validasi, dan uji coba yang dilakukan secara terbatas. Hasil validasi yang diperoleh dari ahli materi menunjukkan rata-rata sebesar $81,30 \%$, ahli media $84 \%$, dan respon peserta didik sebesar 93,33\%. Sehingga dapat disimpulkan bahwa Media Interaktif Program Lectora Inspire berbasis android sangat layak dijadikan sebagai media pembelajaran Akuntansi.
\end{abstract}

Kata kunci: Media Interaktif, Android, Lectora Inspire, Akuntansi.

\begin{abstract}
The development of science and technology in the era of the industrial revolution 4.0 and the implementation of the 2013 curriculum system in learning, teachers were expected to be able to adapt to the existing developments. One way to take advantage of existing technology was to developed interactive media using an android smartphone. By utilizing an android smartphone with an attractive application, students could learn anytime and anywhere. Therefore the learning process went well. Several different applications supported interactive media, one of it which was Lectora Inspire. The purpose of this study was to developed interactive media for the Android-based Lectora Inspire program on service company adjustment journal material.

This research was a type of development research that adapted the $4 D$ development model developed by Thiagarajan which includes the stages of definition, design, development, and dissemination. However, due to the limited time, this research had, it only reached the development stage. The subjects of the research trial were material experts, media experts, and 20 students of class XI Accounting and Financial Institutions 4 SMK Negeri 10 Surabaya. Using a questionnaire as a research instrument, and using quantitative descriptive analysis as a data analysis technique. To determine the feasibility level of interactive media, several steps were taken, they are media review, revision, validation, and limited trials. The validation results obtained from material experts showed an average of $81.30 \%$, media experts $84 \%$, and the response of students was $93.33 \%$.
\end{abstract}


From the result above it can be concluded that the Interactive Media of the Androidbased Lectora Inspire Program is very worthy of being used as a medium for learning Accounting.

Keywords : Interactive Media, Android, Lectora Inspire, Accounting.

\section{PENDAHULUAN}

Pendidikan adalah suatu usaha untuk mempersiapkan generasi penerus bangsa yang unggul baik dalam hal akademik maupun nonakademik untuk menghadapi situasi di masa mendatang melalui bimbingan, dan pelatihan. Pendidikan tidak luput dari permasalahan dan keberhasilan dalam pelaksanaanya. Semakin cepatnya Perkembangan ilmu pengetahuan, teknologi dan seni (IPTEKS) merupakan permasalahan dalam pendidikan. IPTEKS merupakan hasil dari pembaharuan yang tersusun dan teratur dengan baik yang dirancang untuk memenuhi hajat hidup manusia [1]. Teknologi informasi dan komunikasi mempunyai pengaruh besar dalam perubahan dibidang pendidikan [2]

Indonesia menggunakan sistem kurikulum 2013 revisi, dimana peserta didik berperan aktif dalam pembelajaran atau Student center. Prof. John Loughran (salah satu dekan fakultas pendidikan di Indonesia) dalam salah satu seminar menyatakan bahwasanya keaktifan peserta didik dalam pembelajaran dapat membentuk pribadi yang lebih inovatif ketika menyelesaikan masalah, mendapatkan gagasan baru, serta rasa ingin tahu dapat lebih terpacu (Gadjah Mada University, 2016). Melalui perkembangan IPTEK dapat mendukung keaktifan peserta didik dalam pembelajaran. Teknologi mampu menjadikan lingkungan pembelajaran menjadi berpusat pada peserta didik [3]. Sesuai pemaparan Sugrah bahwa dalam teori kontruktivisme guru bertindak sebagai pemberi arah serta fasilitator, peserta didik diberi keluasan untuk mengembangkan wawasan yang telah didapatkan sehingga proses belajar menjadi lebih berarti [4].

Berkembangnya IPTEKS pada era revolusi industry 4.0 serta berlakunya sistem kurikulum 2013 dalam pembelajaran, guru diharapkan dapat menyesuaikan perkembangan zaman yang ada. Sebagai fasilitator merupakan peran guru dalam proses belajar mengajar, yang berarti bahwa ketika pembelajaran guru harus mempersiapkan fasilitas yang layak serta dapat mendukung keberhasilan kegiatan belajar peserta didik. Salah satunya dengan penyajian materi kepada peserta didik dapat diakses secara online maupun offline dengan memanfaatkan teknologi yang ada. Kegiatan pembelajaran tidak harus diperoleh dari buku atau bahan cetakan, melainkan dapat diperoleh dari presentasi visual, internet, video, audio, dan lain sebagainya [2]

Alat untuk mendukung proses pembelajaran, penyampaian materi kepada peserta didik ialah media pembelajaran. Media pembelajaran yakni sebuah alat untuk membantu menyampaikan materi dari guru untuk peserta didik agar pembelajaran berjalan dengan mudah [5]. Media pembelajaran ialah suatu alat bantu penyampaian pesan dalam proses pembelajaran [6]. Media pembelajaran berperan penting untuk mengendalikan kesulitan belajar yang dialami peserta didik. Selain sabagai alat bantu untuk mendukung pembelajaran, media juga sebagai sumber belajar dalam proses pembelajaran. Jenis media dibagi menjadi tiga yakni : media auditif, visual, dan audiovisual [7].

Powerpoint merupakan media yang kerap dipakai di sekolah. Sesuai penelitian yang dilaksanakan Shelviyani mengungkapkan bahwa guru sering menjadikan powerpoint sebagai media pembelajaran [8]. Namun powerpoint dinilai kurang menarik sehingga menyebabkan kebosanan dalam pembelajaran, dengan media powerpoint keaktifan peserta didik tidak sesuai dengan sistem kurikulum yang berlaku. Peserta didik tertarik dengan adanya pembelajaran yang bervariasi dalam penyampaian materinya. lebih banyak orang belajar dengan baik dengan perpaduan kata dan gambar bukan hanya berupa kata-kata [9]

Untuk memberikan kesan yang menarik pada peserta didik saat pembelajaran, diperlukan kombinasi dari beberapa media diantaranya dengan menggabungkan media berbasis audio, visual, maupun berbasis kinestik pada media yang digunakan. Pembelajaran yang memanfaatkan TIK maupun menggabungkan berbagai media agar tercapai tujuan yang diinginkan disebut dengan media pembelajaran interaktif [10]. Dari materi yang disampaikan guru melalui media interktif peserta didik diharapkan mampu mempelajari dengan baik. Dengan bantuan media pembelajaran yang disajikan dengan menarik dapat menambah ketertarikan peserta didik untuk belajar dan memahami materi [11] Penelitian terdahulu menjelaskan bahwasannya dengan memanfaatkan media interaktif dalam pembelajaran dapat mengembangkan pemahaman peserta didik dibanding dengan menggunakan powerpoint [12]. 
Salah satu cara untuk memanfaatkan teknologi untuk menunjang perkembangan media interaktif yakni dengan memanfaatkan smartphone android. Suatu hal yang tidak terpisahkan dari manusia adalah kemunculan smartphone beberapa tahun terakhir [13]. Smartphone dengan sistem android dapat dijadikan sebagai alat penunjang media. Android ialah suatu sistem operasi gerak yang telah dimodifikasi, dirilis sejak Oktober 2013 oleh beberapa ahli IT [13]. Dengan memanfaatkan smartphone android berbantu aplikasi yang menarik peserta didik dapat belajar sewaktu-waktu sehingga pembelajaran berlangsung dengan baik.

Terdapat sejumlah aplikasi yang beragam untuk mendukung media interaktif salah satunya yakni Lectora Inspire. Lectora Inspire ialah suatu aplikasi pendukung media pembelajaran dengan memanfaatkan teknologi informasi serta aplikasi yang dapat membuat presentasi, didirikan oleh Timothy D. Loudermilk, 1999 di Amerika dan mendapatkan penghargaan pada tahun 2011 dibidang elearning inovatif dan terbaik [14]. Lectora telah mewakili solusi e-learning lengkap untuk organisasi pendidikan dan pelatihan yang memiliki sumber daya bawaan yang cepat untuk perkembangan $e$ learning [15].

Selain itu Lectora Inspire juga dilengkapi beberapa template yang menarik dan lengkap, dan menyajikan berbagai evaluasi pembelajaran berupa pilihan ganda, pilihan benar dan salah, serta pernyataan menjodohkan dan dengan memanfaatkan Lectora Inspire materi pembelajaran bisa diakses baik dengan bantuan internet maupun tidak. Penelitian terdahulu menyatakan bahwa media pembelajaran yang memanfaatkan aplikasi Lectora Inspire layak dijadikan media pembelajaran [16]. Penelitian yang dilakukan dengan mengembangkan Lectora Inspire sebagai media pembelajaran akuntansi dinyatakan sangat layak digunakan dengan persentase $87,23 \%$ dari ahli media, $82 \%$ dari ahli materi, serta $97,14 \%$ dari respon siswa [17]. Media interaktif berbasis Lectora Inspire sangat layak untuk dijadikan media pembelajaran pada materi laporan harga pokok perusahaan manufaktur [18].

Salah satu sekolah menengah kejuruan yang mempunyai keahlian bidang Akuntansi dan Keuangan Lembaga adalah SMK Negeri 10 Surabaya, mata pelajaran praktikum akuntansi jasa, dangang, dan manufaktur ialah pelajaran yang wajib diselesaikan oleh peserta didik kelas XI. Salah satu materi dalam praktikum akuntansi yang sering mengalami kendala ialah jurnal penyesuaian [19]. Jurnal penyesuaian ialah jurnal yang digunakan untuk memperbarui saldo pada akun-akun tertentu diakhir periode akuntansi [20]. Dalam hal ini, di SMKN 10 Surabaya pembelajaran masih menggunakan media pembelajaran berupa powerpoint, bahan ajar yang diperoleh secara instan tanpa menyusunnya sendiri, papan tulis, serta metode ceramah yang masih sering digunakan dalam penyampaian materi pembelajaran, hal ini menjadikan peserta didik sulit memahami apa yang telah disampaikan karena merasa bosan, monoton dan seringkali tidak mendengarkan penjelasan guru.

Pada penelitian pengembangan ini difokuskan dengan mengembangkan media interaktif dengan bantuan program Lectora Inspire pada mata pelajaran praktikum akuntansi yang dapat diakses melalui smartphone android milik peserta didik secara online maupun offline kapanpun dan dimanapun yang memuat materi jurnal penyesuaian perusahaan jasa yang dikemas secara menarik, dan dilengkapi beberapa soal diantaranya soal benar-salah sebagai soal evaluasi serta soal pilihan ganda yang dijadikan sebagai acuan untuk mengetahui pemahaman peserta didik. Dengan harapan adanya media interaktif program Lectora Inspire berbasis android bisa mendukung guru dalam penyampaian materi pembelajaran secara menarik serta peserta didik lebih termotivasi untuk belajar.

Penelitian ini bertujuan (1) Mengetahui proses dan mengembangkan produk berupa media interaktif program Lectora Inspire berbasis android, (2) Mengetahui kelayakan media interaktif program Lectora Inspire berbasis android, serta (3) Mengetahui respon peserta didik terhadap media interaktif program Lectora Inspire berbasis android.

\section{METODE}

Jenis penelitian iini ialah pengembangan. Salah satu jenis penelitian yang bertujuan mendapatkan suatu produk serta menilai keberhasilannya disebut dengan penelitian pengembangan [21]. Menerapkan model penelitian 4D yang dikembangkan oleh Thiagarajan yakni Pendefinisian, Perancangan, Pengembangan, dan Penyebaran [22]. Karena keterbatasan kemampuan dan keterjangkauan peneliti dalam melakukan diseminiasi sehingga tahap penyebaluasan produk tidak dilakukan

Dua orang ahli materi, satu orang ahli media, serta 20 peserta didik Kelas XI AKL 4 SMK Negeri 10 Surabaya yang dipilih secara random merupakan subjek uji coba dalam penelitan ini. Para ahli dalam penelitian ini merupakan orang-orang yang berkompeten dalam bidangnya. Menggunakan angket untuk teknik pengumpulan data. Angket ialah kumpulan pertanyaan yang diajukan kepada responden, bertujuan untuk mendapatkan informasi secara lengkap dan sesuai dengan kenyataan [23]. 
Terdapat dua angket dalam penelitian ini, yakni angket terbuka serta angket tertutup. Angket yang cara penyajiannya dilakukan secara sederhana sehingga jawaban yang diberikan dapat sesuai keadaan dan keinginan responden ialah angket terbuka. Sedangkan angket yang cara penyajiannya berbentuk sedemikian rupa dan cara menjawabnya dengan memberikan suatu tanda pada jawaban yang sesuai dengan keinginan atau keadaan responden ialah angket tertutup [23]. Angket terbuka dibagikan kepada para ahli yang berupa lembar telaah berisikan kritik serta saran terhadap media agar dilakukan perbaikan. Angket tertutup berupa angket validasi yang dibagikan kepada para ahli dengan tujuan untuk memahami tingkat kevalidan media interaktif yang dikembangkan, dan untuk mengetahui pendapat peserta didik terkait media diperlukan angket respon siswa.

Berdasarkan angket yang telah diberikan terdapat data kualitatif dan kuantitatif. Angket telaah ahli menghasilkan data kualitatif yakni berupa masukan atas media yang dikembangkan yang selanjutnya akan dilakukan analisis secara deskriptif. Penilaian yang diberikan oleh para ahli melalui angket validasi ahli materi dan media, serta angket respon siswa menghasilkan data kuantitatif. Selanjutnya kelayakan media dapat diketahui melalui data yang telah diperoleh berdasarkan angket validasi ahli dengan perhitungan skala likert 1 sampai dengan 5, perolehan skor 1 menunjukkan sangat tidak baik, dan perolehan skor 5 menujukkan sangat baik. Skor yang didapatkan kemudian dianalisis secara kuantitatif dengan tujuan mengetahui persentase atau tingkat kelayakan media dan dapat disimpulkan apabila mendapatkan persentase $\geq 61 \%$ maka media yang dikembangkan dinyatakan layak.

Data kuantitatif yang didapatkan dari angket respon siswa diperhitungkan dengan skala Guttman 1 untuk pendapat $Y a$, dan 0 untuk Tidak. Skor yang didapatkan kemudian dianalisis secara kuantitatif, bertujuan untuk mengetahui pandangan peserta didik setelah mengoperasikan media interaktif. Hasil yang diperoleh selanjutnya dapat disimpulkan apabila mendapatkan persentase $\geq 61 \%$ maka termasuk dalam kategori sangat baik.

\section{HASIL DAN PEMBAHASAN}

Keterbatasan kemampuan dan keterjangkauan peneliti menyebabkan pada penelitian ini hanya terbatas pada tahap pengembangan.

\section{A. Tahap Pendefinisian}

Langkah utama pada tahap ini yakni analisis ujung depan (awal-akhir), analisis peserta didik, analisis tugas, analisis konsep serta perumusan tujuan pembelajaran. Pada tahap pertama, peneliti melakukan analisis ujung depan sebagai langkah pertama dalam tahap pendefinisian dengan tujuan untuk menetapkan permasalahan yang sedang dihadapi oleh peserta didik kelas XI SMK Akuntansi tepatnya saat pembelajaran praktikum akuntansi. SMK Negeri 10 Surabaya ialah sekolah menengah kejuruan yang mengimplementasikan kurikulum 2013, dimana peran aktif peserta didik dalam pembelajaran merupakan hal yang utama. Materi pembelajaran yang diajarkan oleh guru telah sesuai dengan kompetensi dasar dan indikator yang berlaku yakni KD 3.4 Menganalisis transaksi penyesuaian perusahaan jasa serta KD 4.4 Melakukan pencatatan transaksi penyesuaian untuk perusahaan jasa. Namun, dari hasil analisis yang dilaksanakan peneliti bahwasannya kurikulum yang berlaku di SMK Negeri 10 Surabaya belum terealisasikan dengan baik, penyebabnya adalah kurang aktifnya peserta didik dalam pembelajaran baik bertanya maupun menjawab pertanyaan terkait materi yang disajikan oleh guru.

Kurang aktifnya peserta didik dalam pembelajaran berpengaruh pada tujuan yang ingin dicapai di sekolah kejuruan yakni mempersiapkan peserta didik yang mampu bekerja secara mandiri maupun menjadi manusia yang produktif serta mampu bersaing dibidang pendidikan maupun ketenaga kerjaan terutama pada bidang akuntansi. Salah satu penyebab pembelajaran tidak berlangsung secara aktif karena penggunaan media yang monoton serta kurang menarik. Selain itu salah satu materi praktikum akuntansi jasa, dagang dan manufaktur yang dirasa cukup sulit untuk dipahami adalah jurnal penyesuaian perusahaan jasa. Dengan media pembelajaran yang monoton dan materi pembelajaran yang cukup sulit mengakibatkan ketertarikan peserta didik dalam belajar menjadi berkurang serta tidak bersemangat saat pelaksanaan pembelajaran sehingga pembelajaran berlangsung secara pasif. Perkembangan zaman menuntut agar media pembelajaran dapat menyesuaikan kebutuhan dan capaian pembelajaran [24]

Langkah yang kedua yakni analisis peserta didik, dengan tujuan untuk memahami karakter peserta didik dengan memperhatikan kemampuan, kondisi, dan pengetahuan yang dimiliki sebagai pertimbangan dalam menyusun materi pelajaran dan menentukan media yang akan dikembangkan. Peserta didik Kelas XI AKL 4 SMK Negeri 10 Surabaya dengan beragam karakter merupakan subjek 
uji coba terbatas. Sanjaya berpendapat bahwa kemampuan, minat, pengalaman, dan gaya belajar yang berbeda-beda dari setiap peserta didik dapat diatasi dengan menggunakan media pembelajaran [25]. Hasil dari analisis peserta didik dijadikan pedoman untuk menentukan media pembelajaran yang tepat, yang mampu meningkatkan kemauan peserta didik dalam belajar serta dapat digunakan kapanpun dan dimanapun, salah satunya dengan cara memanfaatkan adanya Smartphone android yang telah banyak peserta didik miliki. Media pembelajaran yang memanfaatkan android menjadikan peserta didik lebih termotivasi dalam mempelajari materi dengan cepat, serta dapat digunakan sewaktu-waktu [26].

Langkah selanjutnya yakni analisis tugas yang bertujuan untuk menganalisis kemampuan peserta didik dalam menafsirkan materi yang telah didapatkan, mengidentifikasi isi materi beserta soal-soal yang akan dibagikan kepada peserta didik. Melalui analisis tugas peneliti memberikan latihan penugasan yang termuat dalam media pembelajaran dengan tipe soal pilihan ganda dan tipe benar salah untuk melihat pemahaman peserta didik setelah menggunakan media interaktif.

Langkah keempat yakni analisis konsep, dengan tujuan mengidentifikasi tingkat pemahaman serta kemampuan peserta didik atas apa yang sudah diajarkan oleh guru, mengidentifikasi konsep inti yang akan disampaikan serta menentukan materi dan soal yang relevan dengan silabus praktikum akuntansi kelas XI.

Perumusan tujuan pembelajaran merupakan langkah terakhir dalam tahap pendefinisian dengan tujuan menetapkan indikator pencapaian pembelajaran dari analisis ujung depan sampai dengan analisis konsep.

\section{B. Tahap Perancangan}

Peneliti mengadakan pemilihan media yang disesuaikan dengan keadaan peserta didik agar mudah mempelajari materi yang disampaikan, pemilihan dilakukan dengan sebaik mungkin tanpa memberatkan peserta didik diberbagai situasi. Tingkat efektivitas pembelajaran dengan menggunakan media interaktif lebih tinggi jika dibandingkan dengan media power point [12] berdasarkan hal tersebut peneliti memilih media interaktif sebagai alat pendukung proses pembelajaran. Penyusunan format tampilan, materi, video, serta penyajian soal pada media interaktif disesuaikan dengan kebutuhan peserta didik serta untuk memberikan kesan yang lebih menarik dalam proses pembelajaran. Sejalan dengan pemaparan Hade dalam penelitian terdahulu bahwa penggunaan gambar dan input suara yang baik dapat menarik perhatian peserta didik dan meningkatkan informasi yang didapatkan [27]. Pemilihan format .apk pada media yang dikembangkan dengan tujuan peserta didik dapat mengakses kapanpun dan dimanapun baik dengan bantuan internet maupun tidak. Mempersiapkan rancangan awal produk dengan menentukan desain tampilan media interkatif, memilih tombol, tulisan, warna yang disesuaikan dengan peserta didik pada jenjang SMK.

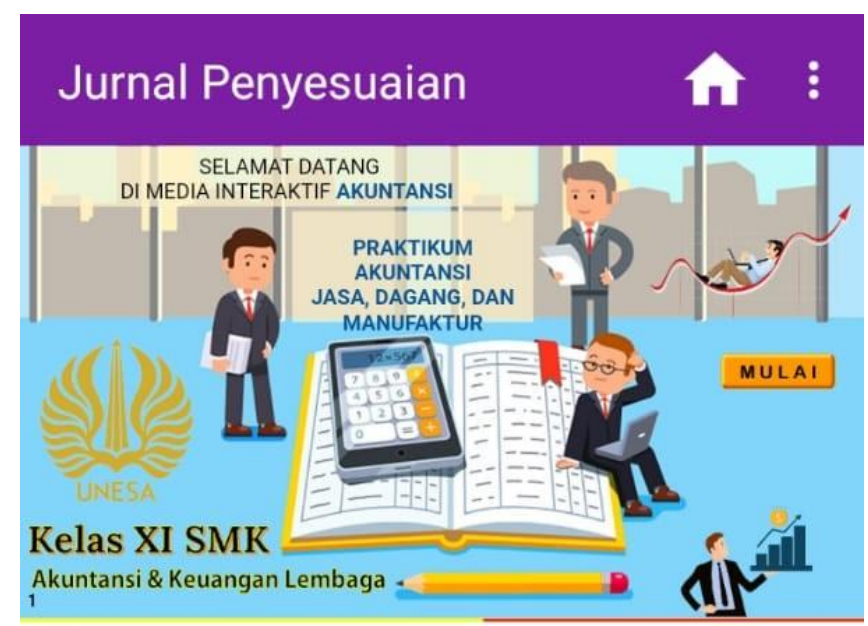

Gambar 1. Tampilan awal media interaktif

Merancang isi media interaktif yang terdiri dari beberapa menu yakni petunjuk, kompetensi, menu media interaktif, materi, evaluasi, pustaka, kuis, dan profil pengembang. Serta mempersiapakan beberapa sumber referensi, referensi diperoleh dari buku praktikum akuntansi kelas XI SMK kurikulum 2013 maupun kurikulum 2013 revisi, dan internet. 


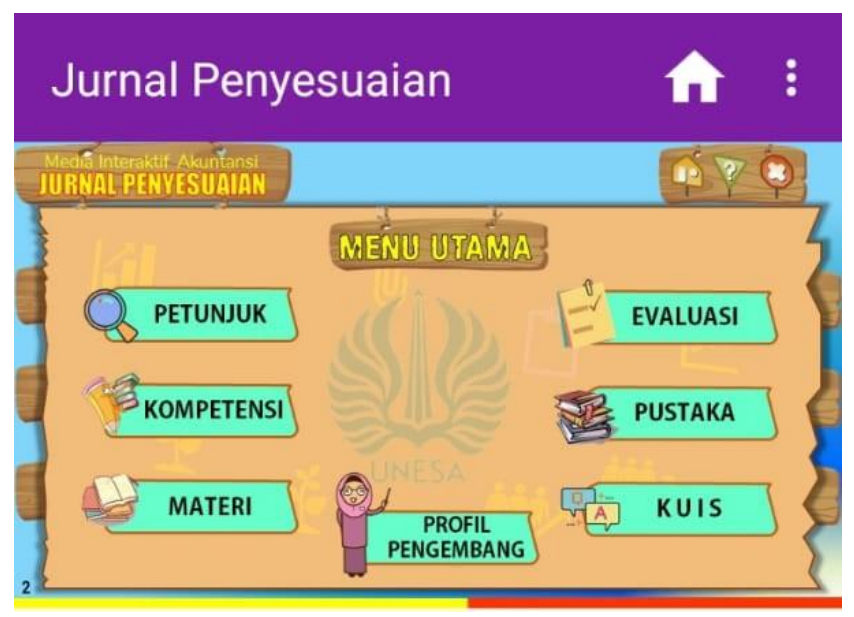

Gambar 2. Tampilan Halaman Menu

\section{Tahap Pengembangan}

Tahap ketiga yang merupakan tahap terakhir pada penelitian ini adalah tahap pengembangan. Tujuan dari tahap ini ialah menghasilkan produk berbentuk media interaktif program Lectora Inspire berbasis andorid yang bisa dimanfaatkan guru untuk membantu proses penyampaian informasi pembelajaran kepada peserta didik dengan baik serta membantu peserta didik menerima informasi dari guru dengan mudah. Penggunaan media interaktif juga mampu meningkatkan keterampilan berpikir kritis peserta didik dibanding menggunakan metode konvensional [28]. Untuk menghasilkan produk peneliti melakukan pemilihan media dan menerapkan rancangan-rancangan yang sudah disusun sebelumnya. Peneliti menetapkan untuk media interaktif dibuat dengan menggunakan bantuan program Lectora Inspire $V 11$ hal ini didasari oleh penelitian terdahulu bahwa salah satu program aplikasi yang layak dijadikan sebagai media pembelajaran ialah Lectora Inspire [16] [29]. Penerapan media pembelajaran berbantu program Lectora Inspire dapat menambah hasil belajar peserta didik serta efektif untuk digunakan [30].

Penelitian yang memanfaatkan Lectora Inspire sebagai media pembelajaran akuntansi memperoleh persentase sebesar $89,13 \%$ dari ahli materi, $84,89 \%$ dari ahli media, dan $94,22 \%$ dari angket respon siswa sehingga media dinyatakan sangat layak [18]. Hasil penelitian Dias, dkk membuktikan bahwasannya media yang menggunakan Lectora Inspire sangat layak dijadikan sebagai media belajar dengan persentase kelayakan sebesar 94,35\% [31]. Setelah menetapkan media interaktif menggunakan Lectora Inspire, agar dapat berbentuk .apk maka dibuild menggunakan website2apk agar dapat dioperasikan melalui Smartphone android. Sebelum digunakan untuk uji coba produk, aplikasi yang sudah berupa .apk dan dapat diakses melalui android perlu diuji kelayakan oleh beberapa ahli melalui beberapa tahapan diantaranya yaitu telaah produk, revisi produk, validasi produk, serta uji coba pada peserta didik yang dilakukan secara terbatas.

Telaah produk yang dilakukan oleh para ahli mempunyai tujuan untuk mendapatkan kritik serta masukan untuk perbaikan media interaktif yang akan dikembangkan. Diperoleh beberapa saran dari proses telaah yakni menambahkan soal-soal dengan model soal Higher Order Thinking Skills (HOTS), memberikan contoh soal ilustrasi dengan studi kasus, menambah penjelasan pada penyelesaian contoh soal yang telah disajikan, serta tampilan desain lebih disesuaikan dengan peserta didik pada jenjang SMK. Kritik dan saran yang diperoleh dijadikan pedoman untuk perbaikan atau revisi media. Setelah proses revisi selesai dan menghasilkan media yang sesuai saran, selanjutnya media divalidasi untuk mengetahui kelayakan media interaktif tersebut. Validasi dari para ahli menghasilkan data kuantitatif yanag dijadikan sebagai dasar untuk memutuskan kelayakan media.

a. Hasil Validasi Ahli Materi

Hasil perolehan validasi media dari ahli materi berdasarkan beberapa komponen diantaranya kualitas isi dan tujuan mendapatkan persentase sebesar $84,28 \%$, dan kualitas intruksional $78,73 \%$. Sehingga rata-rata persentase perolehan adalah sebesar $81,30 \%$ sehingga media dikategorikan sangat layak. Berikut ini ialah rekap hasil validasi dari ahli meteri : 


\begin{tabular}{llcl}
\multicolumn{3}{c}{ Tabel 1. Rekap Hasil Validasi Media } & Dari Ahli Materi \\
\hline No & Variabel & $\%$ & Kriteria \\
\hline 1. & $\begin{array}{l}\text { Kualitas isi dan } \\
\text { tujuan }\end{array}$ & $84,28 \%$ & $\begin{array}{l}\text { Sangat } \\
\text { Layak }\end{array}$ \\
\hline 2. & $\begin{array}{l}\text { Kualitas } \\
\text { intruksional }\end{array}$ & $78,73 \%$ & Layak \\
\hline Rata-rata & $81,30 \%$ & $\begin{array}{l}\text { Sangat } \\
\text { Layak }\end{array}$ \\
\end{tabular}

Sumber : Data diolah peneliti (2021)

b. Hasil Validasi Ahli Media

Hasil perolehan validasi ahli media sebesar $88 \%$ untuk variabel perangkat lunak, dan $80 \%$ untuk komuniikasi visual. Sehingga persentase keseluruhan yang didapatkan untuk kelayakan media interaktif program Lectora Inspire yakni sebesar $84 \%$ yang berarti sangat layak untuk dijadikan media interaktif. Berikut ini merupakan rekap dari hasil validasi ahli media :

\begin{tabular}{|c|c|c|c|}
\hline No & Variabel & $\%$ & Kriteria \\
\hline 1. & $\begin{array}{l}\text { Perangkat } \\
\text { Lunak }\end{array}$ & $88 \%$ & $\begin{array}{l}\text { Sangat } \\
\text { Layak }\end{array}$ \\
\hline 2. & $\begin{array}{l}\text { Komunikasi } \\
\text { Visual }\end{array}$ & $80 \%$ & Layak \\
\hline \multicolumn{2}{|c|}{ Rata-rata } & $84 \%$ & $\begin{array}{l}\text { Sangat } \\
\text { Layak }\end{array}$ \\
\hline
\end{tabular}

Sumber : Data diolah peneliti (2021)

c. Uji Coba Terbatas

Dari hasil validasi yang telah didapatkan, selanjutnya dapat dilakukan uji coba untuk peserta didik kelas XI AKL 4 SMK Negeri 10 Surabaya berjumlah 20 anak. Uji coba dilaksanakan oleh peneliti dengan mengirimkan media interaktif program Lectora Inspire yang sudah berbentuk apk melalui WhatsApp group dan meminta peserta didik untuk mendownload dan menginstal media tersebut pada smartphone masing-masing. Setelah media sudah dapat terinstal dengan baik selanjutnya peserta didik membuka dan mempelajari materi yang telah disajikan. Setelah mempelajari materi peserta didik diperintahkan untuk menyelesaikan beberapa soal yang telah tersedia didalamnya, pengerjaan soal dilakukan untuk melihat pemahaman peserta didik sesudah menggunakan media interaktif materi jurnal penyesuaian.

Untuk memahami respon dari peserta didik atas media yang dikembangkan perlu dilakukan uji coba terbatas serta memerlukan angket respon siswa yang pengisiannya dilakukan setelah peserta didik memahami materi dan mengerjakan soal-soal. Angket disajikan dalam bentuk Google formulir. Angket respon siswa terdiri dari tiga variabel yakni kualitas isi dan tujuan yang mendapatkan persentase sebesar $95 \%$, kualitas intruksional $90 \%$, dan kualitas teknis $95 \%$. Disajikan dalam tabel : 


\begin{tabular}{llcl}
\multicolumn{4}{c}{ Tabel 3. Rekapitulasi Hasil } \\
\hline No & Variabel & $\%$ & Kriteria \\
\hline 1. & $\begin{array}{l}\text { Kualitas isi dan } \\
\text { Tujuan }\end{array}$ & $95 \%$ & Sangat Baik \\
\hline 2. & $\begin{array}{l}\text { Kualitas } \\
\text { Intruksional }\end{array}$ & $90 \%$ & Sangat Baik \\
\hline 3. & Kualitas Teknis & $95 \%$ & Sangat Baik \\
\hline Rata-rata & $93,33 \%$ & Sangat Baik
\end{tabular}

Sumber : Data diolah peneliti (2021)

Hasil keseluruhan angket respon siswa, media interaktif program Lectora Inspire berbasis android menunjukkan bahwa media tersebut sangat baik untuk dijadikan media interaktif Akuntansi dengan persentase keseluruhan sebesar $93,33 \%$. Hasil tersebut menunjukkan pembelajaran yang memanfaatkan media interaktif dapat mengembangkan minat peserta didik dalam belajar, memudahkan pemahaman, dan peserta didik menjadi lebih tertarik dalam pembelajaran [32].

Media interaktif ini merupakan salah satu bentuk dari perkembangan tekonologi informasi dengan memanfaatkan smartphone milik peserta didik, yang diharapkan dengan adanya media pembelajaran berbasis smartphone android peserta didik dapat belajar kapanpun dan dimanapun serta penggunaan smartphone bisa lebih maksimal, tidak hanya untuk hiburan.

\section{SIMPULAN DAN SARAN}

Penelitian pengembangan media interaktif program Lectora Inspire berbasis android ini menggunakan model pengembangan 4D dari Thiagarajan. Karena terbatasnya waktu yang dimiliki peneliti pada tahap terakhir atau penyebarluasan produk tidak dilaksanakan. Media interaktif program Lectora Inspire berbasis android hanya terbatas pada salah satu materi praktikum akuntansi kelas XI. Subyek uji coba dari penelitian ini ialah dua orang ahli materi, satu orang ahli media, serta 20 peserta didik kelas XI Akuntansi dan Keuangan Lembaga 4 SMK Negeri 10 Surabaya.

Untuk mengetahui kelayakan produk diperlukan beberapa tahapan diantaranya yaitu telaah produk, revisi produk, validasi produk, serta uji coba pada peserta didik yang dilakukan secara terbatas. Saran yang diperoleh dari proses telaah para ahli dijadikan patokan untuk revisi media. Setelah proses revisi yang dilakukan oleh peneliti selesai tahap selanjutnya yakni validasi media untuk mengetahui kelayakan media interaktif tersebut.

Media ini dinyatakan sangat layak dari penilaian para ahli. Dari hasil validasi ahli materi memperoleh $81,30 \%$, dari ahli media $84 \%$. Dan dinyatakan sangat baik dengan persentase $93,33 \%$ dari hasil angket respon siswa. Sehingga Media interaktif program Lectora Inspire berbasis android pada materi jurnal penyesuaian perusahaan jasa kelas XI SMK Akuntansi sangat layak digunakan sebagai media pembelajaran akuntansi.

Saran untuk peneliti selanjutnya, diantaranya : 1) Media interaktif program Lectora Inspire berbasis android ini hanya difokuskan pada salah satu materi akuntansi, sehingga diharapkan untuk peneliti selanjutnya dapat memperluas materi yang akan disajikan, 2) Diharapkan peneliti selanjutnya dapat mengembangkan media interaktif yang dapat diakses melalui IOS dengan desain yang lebih menarik. 3) Diharapkan peneliti selanjutnya dapat melanjutkan tahapan pengembangan 4D secara lengkap yakni sampai pada tahap Disseminate atau penyebarluasan produk.

\section{DAFTAR PUSTAKA}

[1] Roesminingsih and L. H. Susarno, Teori dan Praktek Pendidikan, 8th ed. Surabaya: Lembaga Pengkajian dan Pengembangan IImu Pendidikan, FIP UNESA, 2016.

[2] . Jo Shan Fu and J. S. Fu, "ICT in Education : A Critical Literature Review and Its Implications," Int. J. Educ. Dev. Using Inf. Commun. Technol., vol. 9, no. 1, pp. 112-125, 2013.

[3] J. J. Castro Sánchez and E. Chirino Alemán, "Teachers' opinion survey on the use of ICT tools to support attendance-based teaching," Comput. Educ., vol. 56, no. 3, pp. 911-915, 2011, doi: 
10.1016/j.compedu.2010.11.005.

[4] N. U. Sugrah, "Implementasi teori belajar konstruktivisme dalam pembelajaran sains," Humanika, vol. 19, no. 2, pp. 121-138, 2020, doi: 10.21831/hum.v19i2.29274.

[5] A. Mahmudah, "Pengembangan Media Pembelajaran Interaktif Berbasis Lectora Inspire Pada Materi Jurnal Penyesuaian Untuk Siswa Kelas X Akuntansi dan Keuangan Lembaga SMK Negeri 1 Tempel Tahun Ajaran 2018/2019," J. Pendidik. Akunt. Indones., vol. XVII, 2019, doi: https://doi.org/10.21831/jpai.v17i1.26515.

[6] F. J. Rahmah and J. Susilowibowo, "Pengembangan Media Pembelajaran Multimedia Interaktif Pada Kompetensi Dasar Jurnal Penyesuaian Perusahaan Dagang Kelas X AK," J. Pendidik. Akunt., vol. 2, no. 2, pp. 1-9, 2014, [Online]. Available:

https://jurnalmahasiswa.unesa.ac.id/index.php/jpak/article/view/9057/9035.

[7] S. B. Djamarah and A. Zain, Strategi Belajar Mengajar, 5th ed. Jakarta: Rineka Cipta, 2014.

[8] D. V. Shelviyani, S. Santoso, and B. Muchsini, "Pengembangan Media Game Edukasi Berbasis Aplikasi Lectora Inspire Pada Pembelajaran Akuntansi Sebagai Upaya Meningkatkan Belajar Mandiri Siswa SMK," J. "Tata Arta" UNS, vol. 3, no. 3, pp. 42-49, 2017.

[9] M. T. Al-Hariri and A. A. Al-Hattami, "Impact of students' use of technology on their learning achievements in physiology courses at the University of Dammam," J. Taibah Univ. Med. Sci., vol. 12, no. 1, pp. 82-85, 2017, doi: 10.1016/j.jumed.2016.07.004.

[10] N. Marlena, R. Dwijayanti, and M. Edwar, "Pengembangan Media Pembelajaran Multimedia Interaktif Berbasis Flash untuk Meningkatkan Hasil Belajar Mahasiswa," J. Pendidik. Ekon. Dan Bisnis, vol. 6, no. 1, pp. 45-51, 2018, doi: 10.21009/jpeb.006.1.5.

[11] E. D. Saptia and Susanti, "Pengembangan Media Pembelajaran Multimedia Interaktif Pada Matei Pajak Penghasilan Pasal 21 Di Smkn 10 Surabaya," J. Pendidik. Akunt., vol. vol.3, no. no.1, pp. 1-7, 2015.

[12] D. Tarigan and S. Siagian, "Pengembangan Media Pembelajaran Interaktif Pada Pembelajaran Ekonomi," J. Teknol. Inf. Komun. Dalam Pendidik., vol. 2, no. 2, pp. 187-200, 2015, doi: 10.24114/jtikp.v2i2.3295.

[13] S. Ningsih and A. Adesti, "Pengembangan Mobile Learning Berbasis Android pada Mata Kuliah Strategi Pembelajaran Universitas Baturaja," Edcomtech, no. 2, pp. 163-172, 2019.

[14] M. Mas'ud, Multimedia Pembelajaran dengan Lectora, Muhammad N. Yogyakarta: Pustaka.shonif., 2014.

[15] F. A. Toader and E. G. Dragomir, "Designing E-Learning Courses Using Lectora," 2013.

[16] R. Linda, ; Erviyenni, A. M. Noer, ; Nur, A. Oktavianti, and D. N. Sellyna, "Development of Lectora Inspire as Interactive Multimedia Chemistry Learning in Senior High School," J. Pendidik. Kim., vol. 8, no. 3, pp. 188-196, 2016, [Online]. Available: http://jurnal.unimed.ac.id/2012/index.php/jpk.

[17] R. ANDIARSA, "Pengembangan Multimedia Interaktif Berbasis Lectora Inspire Sebagai Media Pembelajaran Pada Mata Pelajaran Akuntansi Keuangan Materi Rekonsiliasi Bank Kelas Xi Akuntansi Smk Negeri 1 Boyolangu," J. Pendidik. Akunt., vol. 5, no. 2, pp. 1-7, 2017.

[18] N. D. Rahmawati and J. Susilowibowo, "Pengembangan Media Pembelajaran Interaktif Berbasis Lectora Inspire Pada Materi Laporan Harga Pokok," J. Teknol. Pendidik., vol. 13, no. 2, p. 107, 2020, doi: 10.24114/jtp.v13i2.19081.

[19] K. B. Nadhya Noor and M. N. Aisyah, "Development of Interactive Learning Media Based on Computer To Improve Student Learning Motivation," J. Pendidik. Akunt. Indones., vol. 16, no. 2, 2018, doi: 10.21831/jpai.v16i2.22054.

[20] C. S. Warren, J. M. Reeve, J. E. Duchac, E. T. Wahyuni, and A. A. Jusuf, Pengantar Akuntansi 1 adaptasi Indonesia, 4th ed. Jakarta Selatan: salemba empat, 2017.

[21] Sugiyono, Metode Penelitian Pendidikan (pendekatan kuantitatif, kualitatif, dan R\&D). Bandung: Alfabeta, 2018.

[22] Trianto, Model Pembelajaran Terpadu. Jakarta: Prestasi Pustaka, 2007.

[23] Riduwan, Skala Pengukuran Variabel-Variabel Penelitian. Jawa Barat: Bandung Alfabeta, 2016.

[24] K. Fikri and S. R. I. Samino, "Pemanfaatan Smartphone Android Sebagai Media Pembelajaran Gitar Di Era Industri 4.0," J. IIm. Pendidik. Citra Bakti, vol. 6, no. 2, pp. 210-219, 2019, doi: 10.5281/zenodo.3551980.

[25] S. Wina, "Media Komunikasi Pembelajaran," Jakarta: Kencana Prenada Media Group, 2014, pp. 73-75.

[26] S. Muyaroah and M. Fajartia, "Pengembangan Media Pembelajaran Berbasis Android dengan menggunakan Aplikasi Adobe Flash CS 6 pada Mata Pelajaran Biologi," Innov. J. Curric. Educ. 
Technol., vol. 6, no. 2, pp. 22-26, 2017, doi: 10.15294/ijcet.v6i2.19336.

[27] S. Gasuku, "Developing Multimedia Programmes for Out-of-School Girls: The Case of GIRLS Inspire in Tanzania," Https://Jl4D.Org/Index.Php/Ejl4D/Article/View/453, vol. 8, no. 1, pp. 162170, 2021.

[28] J. Pendidikan et al., "Pengaruh Media Pembelajaran Interaktif Terhadap Peningkatkan Keterampilan Berpikir Kritis Siswa," J. Pendidik. Sains Indones. (Indonesian J. Sci. Educ., vol. 5, no. 1, pp. 72-80, 2017.

[29] N. Handoyono, Suparmin, and H. Nugroho, "Pengembangan E-Modul Berbasis Lectora Pada Pembelajaran Sistem REM," J. Pendidik. Teknol. dan Kejuru., vol. 17, no. 2, pp. 156-165, 2020.

[30] G. M. R. Firmansyah and Rusman, "Efektivitas Media Pembelajaran Lectora Inspire dalam Meningkatkan Hasil Belajar Peserta didik pada Mata Pelajaran Biologi," Pedagog. J. IImu Pendidik., pp. 80-92, 2019, doi: 10.17509/pdgia.v17i1.16836.

[31] D. J. Antara, A. Adiarta, and N. Santiyadnya, "Pengembangan Media Pembelajaran Interaktif 5 Projects for Beginner Berbasis Lectora Inspire 17 Pada Mata Pelajaran Dasar Elektronika Di Smk Negeri 3 Singaraja," J. Pendidik. Tek. Elektro Undiksha, vol. 7, no. 2, pp. 55-61, 2018, doi: $10.23887 /$ jpte.v7i2.20221.

[32] R. M. Putri, E. Risdianto, and N. Rohadi, "Pengembangan Media Pembelajaran Interaktif Dengan Menggunakan Adobe Captivate Pada Materi Gerak Harmonik Sederhana," J. Kumparan Fis., vol. 2, no. 2, pp. 113-120, 2019, doi: 10.33369/jkf.2.2.113-120. 